Author: JD Mujuzi

\title{
PRISONER TRANSFER TO SOUTH AFRICA: SOME OF THE LIKELY CHALLENGES AHEAD
}

\section{ISSN 1727-3781}

2013 VOLUME 16 No 3

http://dx.doi.org/10.4314/pelj.v16i3.6 


\section{PRISONER TRANSFER TO SOUTH AFRICA: SOME OF THE LIKELY CHALLENGES AHEAD}

\section{JD Mujuzi*}

\section{$1 \quad$ Introduction}

For many years the South African government has been reluctant to enter into prisoner transfer agreements. This reluctance is demonstrated by at least two instances. The first is that in 2000 there was an attempt by an opposition member of parliament to move a private member's Bill on the transfer of offenders between South Africa and other countries. ${ }^{1}$ This Bill, although supported by some officials from the Department of Justice, ${ }^{2}$ was not passed because it was, inter alia, opposed by the Department of Correctional Services since, amongst other things, it did not provide for the cost of the prisoner transfer, and it was not clear if the Correctional Services $\mathrm{ACt}^{3}$ was to be amended to empower the Minister of Correctional Services to administer the law relating to the transfer of offenders. ${ }^{4}$ The Bill was also opposed by Members of Parliament from the ruling party, the African National Congress, on the grounds, amongst others, that it would be "problematic since it would allow for prisoners' sentences to be reduced", there were "the financial implications of housing South Africans presently imprisoned overseas", and "[t]here was some concern over which crimes would be covered under the draft bill." ${ }^{5}$ The second was the case of Patricia Gerber v Government of the Republic of South Africa, ${ }^{6}$ in which the High Court was approached by a South African citizen, Ms Patricia Gerber, whose

Jamil D Mujuzi. LLB (Makerere University), LLM (UFS), LLM (UP), LLD (UWC). Senior lecturer, Faculty of Law, University of the Western Cape (UWC) and Research Fellow, Community Law Centre (UWC). Email: djmujuzi@gmail.com. The author is grateful to Prof Israel Leeman and the anonymous referees for their comments on the drafts of this article.

1 Section 73 of the Constitution of the Republic of South Africa, 1996 (hereafter the Constitution) allows a member of parliament to introduce a private member's bill.

See submissions by Rudman in PMG 2001 http://www.bit.ly/13X2e3f.

Correctional Services Act 111 of 1998.

See submissions by the Department of Correctional Services in PMG 2001 http://www.bit.ly/13X2e3f.

See submissions by Hendrickse and Ncube in PMG 2000 http://www.bit.ly/11kUVEf.

Patricia Gerber v Government of the Republic of South Africa 2010 ZAGPPHC 240 (9 December 2010) (hereafter the Patricia Gerber case). 
son had been imprisoned in Mauritius, for an order to compel the South African government to enter into a prisoner transfer agreement with Mauritius, which was willing to enter into such an agreement. The High Court ${ }^{7}$ declined to make such order holding, inter alia:

\begin{abstract}
That does not avail the applicants as it is based on the narrow view that once Mauritius is prepared to enter into a [Prisoner Transfer Agreement] PTA, the government is somehow compelled to enter into such an agreement without further ado. The ... respondent's submissions that the government has to take into consideration a number of other factors cannot be faulted ... there are 1049 South Africans who are prisoners in Brazil, an as yet undetermined number in other countries and that there are policy considerations to exclude certain types of crimes (for example drug related offences). In other words there are various factors to be considered and for this reason the government has decided not to enter into a PTA with Mauritius. However, the decision has not been cast in stone. It has left open the possibility that it may do so in the future after considering all the other factors that have a bearing on the matter.
\end{abstract}

The Court ${ }^{8}$ concluded that:

The applicant concedes that she may not have a right to insist that the Government enter into a PTA. I am of the view that the reasons given by the ... respondent, objectively considered, are not only sufficient but also cannot be regarded as irrational. They are rationally connected to the decision not to enter into a PTA with Mauritius at this stage and are justifiable. In addition, if the government were to enter into a PTA with Mauritius it may well be accused of being unfair and treating the same or different classes of South Africans imprisoned abroad unequally.

However, the position of the South African government on the issue of prisoner transfer agreements appears to be changing. This change is demonstrated by the following two developments. In its 2011/2012 Annual Report the Department of Correctional Services ${ }^{9}$ states that:

The eight pronged strategy that are [sic] utilised to down manage overcrowding is proving to be effective, while there is a need to make greater impact on the level of overcrowding. The draft protocol on interstate transfers of inmates ${ }^{10}$ has been widely consulted in the [Justice, Crime Prevention, and Security] Cluster

Patricia Gerber para 41.

Patricia Gerber para 43.

Department of Correctional Services Annual Report 2011/201257.

As at the time of writing the author's attempts to access a copy of the draft protocol have been futile. 
and submitted to [the Department of International Relations and Cooperation] via Branch [Africa Correctional Services Association] \& [the Southern African Development Community]. While the interstate transfer approach is driven by the department's approach to rehabilitation and the inability of effective reintegration of foreign nationals into their home countries, such inter-state transfers will also have a positive impact on levels of overcrowding.

The above statement indicates that the Department is working hand in hand with countries in the region to put in place a multilateral prisoner transfer protocol to, reduce the level of overcrowding in South African prisons, amongst other things. In July 2012 the spokesperson for the Department of Correctional Services, Logan Maistry, ${ }^{11}$ reportedly said:

Following a request from Cabinet, a memorandum to approve the adoption of a South African policy position on the PTA has been completed. Once a policy position has been adopted by Cabinet, the specific nature of agreements will be negotiated on a case by case basis. In conjunction with sister departments (including Justice and Home Affairs) the PTA has been initiated and (will follow) due process.

This move was welcomed by civil society. ${ }^{12}$ Whatever the driving force behind this move by the South African government to start the process of putting in place measures to transfer offenders, one could argue that there are at least three factors that could have played a role in influencing South Africa to enter into prisoner transfer arrangements. The first factor is that a large number of foreign nationals are serving prison terms in South African prisons. Although the author has not had access to the information to determine accurately the number of foreign nationals in South African prisons, it is fair to estimate that they are in their thousands. Statistics from the Department of Correctional Services show that as at 17 August 2010 there were 4868 foreign nationals in South African prisons. ${ }^{13}$ In April 2012 a Member of Parliament, Mr Selfe, submitted that "[t]here were 10000 people from Zimbabwe, Mozambique and Botswana in local prisons" and that "[r]eturning them was not

11 See Mhlana $2012 \mathrm{http}: / /$ www.bit.ly/128pSHi. It was also reported in early 2012 that the "Ministry of Correctional Services says that discussions around the prisoner transfer agreement are at an advanced stage." See Pillay 2012 http://www.bit.ly/13PDc7N.

12 See comments reportedly made by West (founder of the NGO "Locked-Up") in Pillay 2012 http://www.bit.ly/13PDc7N.

13 See Department of Correctional Services 2010 http://www.bit.ly/KVL7tz. 
happening fast enough."14 In June 2011 the Minister of Correctional Services is reported to have informed parliament that there were "4 982 sentenced foreigners in SA prisons. Of this total, 1913 come from Zimbabwe, and 1449 from Mozambique." The Minister added that "605 sentenced offenders come from Lesotho, 100 from Swaziland, 11 from Namibia and 10 from Botswana" and that there were 184 Nigerian sentenced offenders. ${ }^{15}$

The second factor is that there are a large number of South African nationals serving prison sentences in foreign countries. It is estimated that there are almost a thousand South Africans serving their sentences abroad. ${ }^{16}$ These South Africans are imprisoned in countries such as Brazil, the United Kingdom, and Peru, most of them on drug-related charges. ${ }^{17}$ There has been an increase in media attention on the plight of South Africans imprisoned abroad, and government has been called upon by the families of the South Africans imprisoned abroad to enter into prisoner transfer agreements with some of these countries and bring those South Africans back to South Africa to serve their sentences. ${ }^{18}$ The third and final factor could be that South Africa has ratified two international treaties which contain provisions encouraging states parties to enter into prisoner transfer arrangements as one of the ways to effectively implement these treaties. These treaties are the United Nations Convention against Transnational Organised Crime ${ }^{19}$ and the United Nations Convention against Corruption. ${ }^{20}$

Article 17 of the United Nations Convention against Transnational Organised Crime provides that:

States Parties may consider entering into bilateral or multilateral agreements or arrangements on the transfer to their territory of persons sentenced to

\footnotetext{
Submission by Selfe in PMG 2012 http://www.bit.ly/12G8fF3.

See SAPA 2011 http://www.bit.ly/mHpaci.

See Pillay $2012 \mathrm{http}: / /$ www.bit.ly/13PDc7N.

See Jones 2009 http://www.bit.ly/11kVgGY.

Jones 2009 http://www.bit.ly/11kVgGY.

See a 17 of the United Nations Convention against Transnational Organised Crime (2000). South Africa ratified this treaty on 24 February 2004.

20 See a 45 of the United Nations Convention against Corruption (2003). South Africa ratified this treaty on 24 November 2004.
} 
imprisonment or other forms of deprivation of liberty for offences covered by this Convention, in order that they may complete their sentences there.

Article 45 of the United Nations Convention against Corruption (2003) provides that:

States Parties may consider entering into bilateral or multilateral agreements or arrangements on the transfer to their territory of persons sentenced to imprisonment or other forms of deprivation of liberty for offences established in accordance with this Convention in order that they may complete their sentences there.

South Africa ratified these two treaties without reservations to the above two articles. $^{21}$ This means that South Africa has an obligation to implement these treaties. $^{22}$ Now that South Africa is on its way to establishing a prisoners transfer agreement or agreements, the time is ripe to highlight some of the challenges that are likely to be confronted in implementing such arrangements. ${ }^{23}$

\section{$2 \quad$ Nature of the agreements}

The first challenge is probably the nature of the agreements that South Africa is likely to enter into. As indicated earlier, the spokesperson for the Department of Correctional Services stated that South Africa will negotiate prisoner transfer agreements on a case by case basis. It is not clear what factors will be considered in deciding with which countries South Africa will sign a prisoner transfer agreement and with which it will not. The decision could be based inter alia on the number of foreign nationals of a given country in South African prisons or the number of South African nationals in a given country's prisons. The greater the number, the more likely it is that such an agreement will be signed, because such high numbers of prisoners would be straining South African resources. Although South Africa has not made a final decision in respect of its approach regarding prisoner transfer

21 South Africa made a reservation to a 35(2) of the Organised Crime Convention, which has to do with the jurisdiction of the International Court of Justice.

22 For a detailed discussion of the legal implications of treaties ratified by South Africa see Glenister v President of the Republic of South Africa 20113 SA 347 (CC) 374-5; and generally Dugard International Law 47-80.

23 It should be stated that in terms of s 297B of the Criminal Procedure Act 51 of 1977, a suspended sentence imposed in a different country can be put into effect in South Africa. However, it is beyond the scope of this paper to discuss this section. 
agreements, it is the author's view that the best approach would be for South Africa to adopt more than one approach on the issue of prisoner transfer, because the practice of countries such as the United Kingdom ${ }^{24}$ and Canada ${ }^{25}$ with experience in the transfer of offenders shows that they have followed a multifaceted approach. A multifaceted approach is called for because it would enable South Africa to transfer offenders to and from as many countries as possible - countries that are states parties to the multilateral agreements, as well as those with which South Africa has signed bilateral prisoner transfer agreements.

One approach would be the promulgation of prisoner transfer legislation. This would easily facilitate the transfer of offenders, especially between countries in Africa with similar legislation, such as, Nigeria, Namibia, Malawi, Zimbabwe, Zambia, Mauritius, Tanzania, Uganda, Ghana and Swaziland. Such legislation would be the basis upon which bilateral prisoner transfer arrangements could be made. This legislation could provide for circumstances in which prisoners could be transferred to and from South Africa, whether or not such transfers are based on multilateral or bilateral treaties. The legislation could for example provide that in cases where there is no treaty between South Africa and a foreign country on the transfer of offenders, the relevant minister in South Africa, who could be the minister of justice or the minister of foreign relations, would enter into an administrative arrangement with the foreign country to transfer offenders in accordance with the relevant legislation. ${ }^{26}$ Such transfers have, for example, taken place between Hong Kong and some other countries. $^{27}$

The second approach would be the one suggested by the DCS spokesperson, that is, that the South Africa proceed on a case by case basis. This approach has been

24 The United Kingdom ratified the Council of Europe's Convention on the Transfer of Sentenced Persons (1985) and the Scheme on the Transfer of Sentenced Persons within the Commonwealth (1990) and has signed bilateral prisoner transfer agreements with over 20 countries.

25 Canada has ratified the Council of Europe's Convention on the Transfer of Sentenced Persons (1985), the Inter-American Convention on Serving Criminal Sentenced Abroad (1993) and the Scheme on the Transfer of Sentenced Persons within the Commonwealth (1990) and has signed bilateral prisoner transfer agreements with 14 countries. See Correctional Services of Canada 2012 http://www.bit.ly/11kVSMX.

26 See for example s 31 of the Canadian International Transfer of Offenders Act of 2004 c21.

27 See Wan 2008 Brook J Int'l L 463-501. 
adopted between some African countries, such as between Zambia and Mozambique, ${ }^{28}$ Ghana and Nigeria, ${ }^{29}$ Mauritius and Tanzania, ${ }^{30}$ Mozambique and Malawi, ${ }^{31}$ and Malawi and Zambia, ${ }^{32}$ and also by the United States of America with countries such as Bolivia, Mexico, France, Panama, Peru, Thailand, Turkey, Hong Kong, and Canada, ${ }^{33}$ and by the United Kingdom with various African, Asian and Latin American countries. ${ }^{34}$ The third approach would be for South Africa to ratify

28 See Lusaka Times 2011 http://www.bit.ly/1aEjCy4.

29 See Modern Ghana News 2010 http://www.bit.ly/17UXP6P.

30 See Agreement between the Government of the United Republic of Tanzania and the Government of the Republic of Mauritius on the Transfer of Convicted Offenders (2008).

31 See allAfrica $2012 \mathrm{http}: / /$ www.bit.ly/16d7zVL.

32 See allAfrica $2012 \mathrm{http}: / /$ www.bit.ly/RBrlEU.

33 Abbell International Prisoner Transfer 189-250.

34 These agreements are: Agreement between the Government of the United Kingdom of Great Britain and Northern Ireland and the Republic of Uganda on the Transfer of Convicted Persons (2 June 2009); Agreement between the Government of the United Kingdom of Great Britain and Northern Ireland and the Government of the Republic of Ghana concerning the Transfer of Prisoners (17 July 2008); Agreement between the Government of the United Kingdom of Great Britain and Northern Ireland and the Government of the Republic of Rwanda on the Transfer of Sentenced Persons (11 February 2010); Treaty between the Government of the United Kingdom of Great Britain and Northern Ireland and the Great Socialist People's Libyan Arab Jamahiriya on the Transfer of Prisoners (17 November 2008); Agreement between the Government of the United Kingdom of Great Britain and Northern Ireland and the Government of the Kingdom of Morocco on the Transfer of Convicted Offenders (21 February 2002); Agreement between the Government of the United Kingdom of Great Britain and Northern Ireland and the Government of Antigua and Barbuda on the Transfer of Prisoners (23 June 2003); Agreement between the Government of the United Kingdom of Great Britain and Northern Ireland and the Government of the Federative Republic of Brazil on the Transfer of Prisoners (20 August 1998) Agreement between the Government of the United Kingdom of Great Britain and Northern Ireland and the Government of Barbados on the Transfer of Sentenced Persons (3 April 2002); Agreement between the Government of the United Kingdom of Great Britain and Northern Ireland and the Government of the Government of the Republic of Cuba on the Transfer of Prisoners (13 June 2002); Agreement between the Government of the United Kingdom of Great Britain and Northern Ireland and the Republic of Nicaragua on the Transfer of Prisoners (6 September 2005); Agreement between the Government of the United Kingdom of Great Britain and Northern Ireland and the Government of the Government of the Dominican Republic on the Transfer of Prisoners (18 February 2003); Agreement between the Government of the United Kingdom of Great Britain and Northern Ireland and the Government of the Bolivarian Republic of Venezuela on the Transfer of Sentenced Persons (12 June 2002); Agreement between the Government of the United Kingdom of Great Britain and Northern Ireland and the Government of the Republic of India on the Transfer of Convicted Persons (18 February 2005); Agreement between the Government of the United Kingdom of Great Britain and Northern Ireland and the Government of St Lucia on the Transfer of Prisoners (27 April 2006); Agreement between the Government of the United Kingdom of Great Britain and Northern Ireland and the Government of the Cooperative Republic of Guyana on the Transfer of Prisoners (5 April 2002); Agreement between the Government of the United Kingdom of Great Britain and Northern Ireland and the Government of the Islamic Republic of Pakistan on the Transfer of Prisoners (24 August 2007); Agreement between the Government of the United Kingdom of Great Britain and Northern Ireland and the Government of the Republic of Peru on the Transfer of Sentenced Persons (7 March 2003); Agreement between the Government of the United Kingdom of Great Britain and Northern Ireland and the Government of the Democratic Socialist Republic of Sri Lanka on the 
the two ${ }^{35}$ multilateral treaties on the transfer of offenders - the Council of Europe's Convention on the Transfer of Sentenced Persons (1985), and the Inter-American Convention on Serving Criminal Sentences Abroad (1993). Although these are both regional treaties, they are open for ratification by countries outside the relevant regions, and indeed some countries outside these regions have ratified these treaties. The Inter-American Convention on Serving Criminal Sentences Abroad (1993) has been ratified by Saudi Arabia and the Czech Republic, ${ }^{36}$ and the Council of Europe's Convention on the Transfer of Sentenced Persons (1985) has been ratified by the following non-Council of Europe member states: Australia, Bahamas, Bolivia, Canada, Chile, Costa Rica, Ecuador, Honduras, Israel, Japan, Korea, Mauritius, Mexico, Panama, Philippines, Tonga, Trinidad and Tobago, the United States of America and Venezuela. ${ }^{37}$ By ratifying the Council of Europe's Convention on the Transfer of Sentenced Persons (1985) and the Inter-American Convention on Serving Criminal Sentences Abroad (1993), South Africa would be able to have its nationals who are imprisoned in states parties to these treaties transferred to South Africa on the basis of these treaties.

The ratification of these two treaties would save South Africa the time and resources that would have been spent in entering into prisoner transfer arrangements with each and every state party to these treaties. This is an approach that many countries are increasingly adopting and that explains why countries are increasingly ratifying these treaties. Related to the above is the Scheme for the Transfer of Convicted Offenders within the Commonwealth (1990). This Scheme, as the name

Transfer of Prisoners (6 February 2003); Treaty between the Government of the United Kingdom of Great Britain and Northern Ireland and the Lao People's Democratic Republic on the Transfer of Sentenced Persons (7 May 2009); Agreement between the Government of the United Kingdom of Great Britain and Northern Ireland and the Kingdom of Saudi Arabia on the Transfer of Sentenced Persons (2 January 2012); Agreement between the Government of the United Kingdom of Great Britain and Northern Ireland and the Government of the Republic of Suriname on the Transfer of Prisoners (29 June 2002); and Treaty between the Government of the United Kingdom of Great Britain and Northern Ireland and the Socialist Republic of Vietnam on the Transfer of Sentenced Persons (12 September 2008).

Although there is a United Nations Model Treaty on the Transfer of Convicted Persons, the author is not aware of any country that has transferred offenders on the basis of this model treaty. The two treaties referred to above are those that have been implemented by states parties.

36 See OAS Date Unknown http://www.bit.ly/119Xt7T.

37 See Council of Europe 2013 http://www.bit.ly/15CifwK. 
suggests, regulates the transfer of offenders between Commonwealth countries. ${ }^{38}$ South Africa has been a member of the Commonwealth since 1994 - having joined in 1931 and left in $1961 .^{39}$ The Scheme, which has been ratified by countries, such as, Malawi, Nigeria, the United Kingdom, and Sri Lanka, ${ }^{40}$ could also form the basis for the transfer of offenders between South Africa and Commonwealth countries. The author is not aware of the South African government's position pertaining to the Scheme, but in its submissions on the Transfer of Convicted Offenders Bill, the Department of Correctional Services ${ }^{41}$ stated that:

several discussions did take place with the Department of Foreign Affairs as to [the] possibility to utilise the Commonwealth Scheme for the Transfer of Convicted Prisoners ... [as the] Scheme have [sic] the benefit that the [sic] if South Africa accede [sic] to it and it is incorporated in law, all the Commonwealth Countries are included and then it is not necessary to enter into a bilateral agreement with every country.

\section{$3 \quad$ Fair trial}

Section 35(3) of the South African Constitution guarantees the right to a fair trial. It provides that every accused person has a right to a fair trial "which includes" the 15 listed rights. ${ }^{42}$ In Bogaards $v S^{43}$ the Constitutional Court held that in South African

38 It provides inter alia for the following: the purpose of the transfer (a 1); the conditions that have to be met by the administering country and the sentencing country before the transfer (a 4); the obligations imposed on the sentencing country (a 5); the offender's consent to the transfer and how it should be verified (a 8); the effect of the transfer for both the sentencing and the administering states (aa 10 and 11); the continued enforcement of the sentence (a 12); pardon, amnesty, commutation and review of sentence (a 13); information on enforcement (a 15) and the costs of the transfer (a 17).

39 See The Commonwealth Date Unknown http://www.bit.ly/YsnMVT.

40 See Parliament UK 2012 http:www.//bit.ly/140XBSY.

41 See the submission by the Department of Correctional Services in PMG 2001 http://www.bit.ly/13X2e3f.

42 These rights are: (a) to be informed of the charge with sufficient detail to answer it; (b) to have adequate time and facilities to prepare a defence; (c) to be given a public trial before an ordinary court; (d) to have the trial begin and conclude without unreasonable delay; (e) to be present, when being tried; $(f)$ to choose, and be represented by, a legal practitioner, and to be informed of this right promptly; $(\mathrm{g})$ to have a legal practitioner assigned to the accused person by the state and at state expense, if substantial injustice would otherwise result, and to be informed of this right promptly; $(\mathrm{h})$ to be presumed innocent, to remain silent, and not to testify during the proceedings; ( $\mathrm{i}$ ) to adduce and challenge evidence; ( $j$ ) not to be compelled to give selfincriminating evidence; $(k)$ to be tried in a language that the accused person understands or, if that is not practicable, to have the proceedings interpreted in that language; (I) not to be convicted for an act or omission that was not an offence under either national or international law at the time it was committed or omitted; $(\mathrm{m})$ not to be tried for an offence in respect of an 
law "the understanding of what constitutes a fair trial is flexible" and that trials "are required to be conducted in accordance with general open-ended notions of justice." The Court added that "[t]he opening words [of section 35(3)] illustrate that the scope of the right to a fair trial extends beyond the listed rights." ${ }^{44}$ In their interpretation of section 35(3) of the Constitution, South African courts have developed a rich jurisprudence on the right to a fair trial. ${ }^{45}$

The picture that emerges from the jurisprudence of the South African courts is that there have been some cases where courts have held that a violation of a right listed under section 35(3) of the Constitution amounted to an irregularity which rendered the trial unfair, prompting the setting aside of the conviction and the sentence. ${ }^{46}$ If the person in question is in prison, once the conviction and the sentence are set aside he has to be released from prison immediately unless his continued imprisonment can be justified on other grounds. In the context of prisoner transfer arrangements, one cannot rule out the possibility that some South Africans transferred from other countries to serve their sentences in South Africa could challenge their continued imprisonment in South Africa on the basis that the conviction on which their sentence was based was as a result of an unfair trial. The argument could be that had their trial been conducted in South Africa in a similar manner as it was conducted in the foreign country, it might have been regarded as unfair for failing to meet one or more of the requirements under section 35(3) of the South African Constitution, and also the requirements set in international treaties to which South Africa is a party, such as those under article 14 of the International

act or omission for which that person has previously been either acquitted or convicted; $(n)$ to be entitled to the benefit of the least severe of the prescribed punishments if the prescribed punishment for the offence has been changed between the time that the offence was committed and the time of sentencing; and (o) to be entitled to appeal to, or to a review by, a higher court. Bogaards v S 20131 SACR 1 (CC) para 51.

44 Bogaards v S 20131 SACR 1 (CC) para 101. See also S v Dzukuda; S v Tshilo 20002 SACR 443 (CC) para 9 where the Constitutional Court states that the opening words of $s$ 35(3) "[I]ndicate that such specification is not exhaustive of what the right to a fair trial comprises. It also does not warrant the conclusion that the right to a fair trial consists merely of a number of discrete sub-rights, some of which have been specified in the subsection and others not. The right to a fair trial is a comprehensive and integrated right, the content of which will be established, on a case by case basis, as our constitutional jurisprudence on s 35(3) develops."

45 See generally Schwikkard "Arrested, Detained and Accused Persons" 737-797.

46 See for example Mapule v S 2012 ZASCA 80 (30 May 2012) and the decisions discussed therein as well as $S v$ Mofokeng 20131 SACR 143 (FB). 
Covenant on Civil and Political Rights (1966) (hereafter the ICCPR) ${ }^{47}$ and article 7 of the African Charter on Human and Peoples' Rights (1981) (hereafter the African Charter). ${ }^{48}$ It should be noted that the South African Constitutional Court has held that the South African Constitution does not have extra-territorial application. ${ }^{49}$ It would therefore be difficult to sustain the argument that the offender's trial was unfair because it was conducted under circumstances that did not fully comply with section 35(3) and that therefore his or her continued imprisonment in South Africa on the basis of a conviction based on such a trial would be contrary to section $12(1)(a)^{50}$ of the Constitution which provides that "[e]veryone has the right to freedom and security of the person, which includes the right not to be deprived of freedom arbitrarily or without a just cause". The European Court of Human Rights has held in Drozd and Janousek $v$ France and Spain, ${ }^{51}$ that "[t]he Contracting States are... obliged to refuse their co-operation [in enforcing a sentence] if it emerges that the conviction is the result of a flagrant denial of justice." ${ }^{52}$ The United Kingdom

47 Article 14 of the ICCPR provides that: "(2) Everyone charged with a criminal offence shall have the right to be presumed innocent until proved guilty according to law.(3) In the determination of any criminal charge against him, everyone shall be entitled to the following minimum guarantees, in full equality: (a) To be informed promptly and in detail in a language which he understands of the nature and cause of the charge against him; (b) To have adequate time and facilities for the preparation of his defence and to communicate with counsel of his own choosing; (c) To be tried without undue delay; (d) To be tried in his presence, and to defend himself in person or through legal assistance of his own choosing; to be informed, if he does not have legal assistance, of this right; and to have legal assistance assigned to him, in any case where the interests of justice so require, and without payment by him in any such case if he does not have sufficient means to pay for it; (e) To examine, or have examined, the witnesses against him and to obtain the attendance and examination of witnesses on his behalf under the same conditions as witnesses against him; ( $f$ ) To have the free assistance of an interpreter if he cannot understand or speak the language used in court; $(\mathrm{g}$ ) Not to be compelled to testify against himself or to confess guilt."

Article 7 of the African Charter on Human and Peoples' Rights (1981) provides that: "(1) Every individual shall have the right to have his cause heard. This comprises: (a) the right to an appeal to competent national organs against acts of violating his fundamental rights as recognized and guaranteed by conventions, laws, regulations and customs in force; (b) the right to be presumed innocent until proved guilty by a competent court or tribunal; (c) the right to defence, including the right to be defended by counsel of his choice; (d) the right to be tried within a reasonable time by an impartial court or tribunal. (2) No one may be condemned for an act or omission which did not constitute a legally punishable offence at the time it was committed. No penalty may be inflicted for an offence for which no provision was made at the time it was committed. Punishment is personal and can be imposed only on the offender." 
High Court also held in Samantha Orobator $v$ Governor of HMP Holloway and Secretary of State for Justice: ${ }^{53}$

\begin{abstract}
$[\mathrm{H}] \mathrm{er}$ claim that she has been detained in the UK unlawfully cannot succeed unless it is shown that she suffered a flagrant denial of justice in Laos. For the reasons that we have given, she has not been able to satisfy this high test. The test is rightly set very high. That is because it is important not to jeopardise or undermine the treaties for the repatriation of prisoners which the UK now has with many countries, so that those who are convicted abroad can serve their sentences here. If persons who have been convicted and sentenced abroad and have procured their transfer to the UK were easily able to obtain their liberty by challenging the fairness of their convictions, there would be a grave danger that these important treaties would be set at nought. That would be highly regrettable.
\end{abstract}

Experience from other parts of the world illustrates what could constitute a flagrant denial of justice. In Stoichkov v Bulgaria, ${ }^{54}$ the European Court of Human Rights held that criminal proceedings that were held in absentia, and whose re-opening was subsequently refused, without any evidence that the accused had waived his right to be present during the trial, amounted to a flagrant denial of justice. Recently the High Court in the United Kingdom in the case of Omar Othman Aka Abu Qatada v Secretary of State for the Home Department $t^{55}$ held that deporting the applicant to Jordan where "there was a real risk" that evidence obtained by torture would be admitted at his retrial posed a "a real risk that he would be subject to a flagrant denial of justice. ${ }^{56}$ It is submitted that in the light of the fact that the South African Constitution provides that the accused's right to a fair trial includes the right "to be present when being tried", ${ }^{57}$ a person's trial in absentia, unless justified in terms of the law, ${ }^{58}$ would be a flagrant denial of justice. Furthermore, in the light of the fact that South African courts have held that evidence obtained through torture will

53 Samantha Orobator $v$ Governor of HMP Holloway and Secretary of State for Justice [2010] EWHC 58 (Admin) para 140.

54 Stoichkov v Bulgaria Application No 9808/02 (24 March 2005) para 56.

55 Omar Othman Aka Abu Qatada v Secretary of State for the Home Department [2013] EWCA Civ 277.

56 Omar Othman Aka Abu Qatada v Secretary of State for the Home Department [2013] EWCA Civ 277 para 58.

57 Section 35(3)(e) of the Constitution.

58 See, for example, s 159 of the Criminal Procedure Act 51 of 1977 for the circumstances in which criminal proceedings may take place in the absence of the accused. 
always render a trial unfair and also be detrimental to the administration of justice, ${ }^{59}$ a conviction based on evidence obtained through torture would be obtained as a result of a flagrant denial of justice.

We should recall that section 39 of the South African Constitution provides that:

(1) When interpreting the Bill of Rights, a court, tribunal or forum - (b) must consider international law; and (c) may consider foreign law.

South African courts have referred to the jurisprudence not only of the European Court of Human Rights but also of the courts in the United Kingdom in interpreting the Bill of Rights. ${ }^{60}$ It is argued that in cases of prisoner transfer, such jurisprudence could also be of guidance, because, as stated earlier, the South African Constitution does not have extra-territorial application. However, the issue becomes different if the argument is that a trial did not meet the requirements of a fair trial under international law - that is, under the ICCPR and the African Charter. In such a case, South African courts would be called upon to assess whether the trial in question was in accordance with those international treaties or not. The response to this argument could be that the Constitution allows South African courts to refer to international law in interpreting the Bill of Rights but not to interpret international law. If an offender is of the view that his trial was contrary to these international human rights instruments and that therefore his continued detention in South Africa, with the approval of the South African courts, is contrary to South Africa's international human rights obligations, he then has the right under the relevant instruments to approach the appropriate treaty enforcement bodies. There is

59 See $S$ v Mthembu 20082 SACR 407 (SCA); and Ferreira v Levin; Vryenhoek v Powell 19961 SA 984 (CC).

60 See generally Currie and De Waal Bill of Rights Handbook 159-160 (on the issue of international law) and the following cases with regard to the decisions of the British courts that South African courts have referred to in interpreting the Bill of Rights: Mthembi-Mahanyele $v$ Mail \& Guardian Ltd 20043 All SA 511 (SCA) para 53; South African Broadcasting Corporation Limited $v$ Thatcher 20054 All SA 353 (C) para 54; and Pharmaceutical Manufacturers Association of South Africa: In re Ex Parte President of the Republic of South Africa 20002 SA 674 (CC). In Oldwage $v$ Louwrens 20041 All SA 532 (C) para 4 the Court stated that "[f]oreign case law, in particular judgments of the English courts, although generally [they] do not constitute a binding precedent to our courts, have always had considerable persuave [sic] force and are often referred to by our courts..." 
precedent that indeed some South Africans have taken South Africa to those bodies in a bid to ensure that their rights are protected. ${ }^{61}$ The challenge is that South Africa does not appear to be taking these bodies seriously. ${ }^{62}$ Be that as it may, this could pose a problem for South Africa. For example, the African Commission held recently that Egypt should release prisoners whose trial was conducted contrary to article 7 of the African Charter. ${ }^{63}$ What would be the response of the South African courts to such a recommendation? It is a question that is not easy to answer, especially in view of the fact that the decisions of the human rights bodies are not binding.

\section{Conversion versus continued enforcement}

Another issue that South Africa is likely to have to grapple with in the transfer of offenders is whether the prisoner transfer arrangement would allow it to convert the offender's sentence into a different sentence provided for under South African law or only allow it to continue to enforce the sentence imposed in the sentencing state. This question is important as it may determine whether the offender consents to the transfer or whether the sentencing state agrees to the transfer, as some offenders might refuse to consent to the transfer if the sentence in question will not be converted into a South African sentence ${ }^{64}$ and some countries might refuse to consent to the transfer if the offender's sentence is to be converted into a South African sentence. ${ }^{65}$ of the two multilateral treaties on prisoner transfer, that is, the

61 See Garreth Anver Prince $v$ South Africa Communication 255/02 (African Commission on Human and Peoples' Rights) alleging the violation of his right to freedom of worship; and Gareth Anver Prince v South Africa 1474/2006 (Human Rights Committee) - freedom of worship and religion; Bradley McCallum $v$ South Africa Communication No 1818/2008 UN Doc CCPR/C/100/D/1818/2008 (2010) freedom from torture.

62 Bradley McCallum $v$ South Africa Communication No 1818/2008 UN Doc CCPR/C/100/D/1818/2008 (2010) in which the South African government ignored repeated calls from the Human Rights Committee to respond to the complainant's allegations.

63 See Egyptian Initiative for Personal Rights and Interights $v$ Arab Republic of Egypt, Communication 334/06 (decided at the $9^{\text {th }}$ extra-ordinary session held from 23 February to 3 March 2011).

64 See for example Smith $v$ Germany Application No 27801/05 (1 April 2010) paras 40-41 and Buijen v Germany Application No 27804/05 (1 April 2010) paras 41-42 where the offenders argued that they would not have pleaded guilty to the charges against them if they knew that the prosecutor would oppose the conversion of their sentences by the Dutch authorities.

65 For example, Thailand refused to sign a prisoner transfer agreement with The Netherlands because The Netherlands wanted the treaty to include a provision that would allow it to convert the transferred sentence. See The Queen on the Application of: Steven Willcox v Secretary of 
Inter-American Convention on Serving Criminal Sentences Abroad (1993) and the Council of Europe's Convention on the Transfer of Sentenced Persons (1985), it is only the latter that provides for both conversion and continued enforcement. Article 10 of the Convention on the Transfer of Sentenced Persons (1985) provides for continued enforcement in the following terms:

1. In the case of continued enforcement, the administering State ${ }^{66}$ shall be bound by the legal nature and duration of the sentence as determined by the sentencing State.

2. If, however, this sentence is by its nature or duration incompatible with the law of the administering State, or its law so requires, that State may, by a court or administrative order, adapt the sanction to the punishment or measure prescribed by its own law for a similar offence. As to its nature, the punishment or measure shall, as far as possible, correspond with that imposed by the sentence to be enforced. It shall not aggravate, by its nature or duration, the sanction imposed in the sentencing State, nor exceed the maximum prescribed by the law of the administering State.

Article 11 provides for conversion in the following terms

In the case of conversion of sentence, the procedures provided for by the law of the administering State apply. When converting the sentence, the competent authority: (a) shall be bound by the findings as to the facts insofar as they appear explicitly or implicitly from the judgment imposed in the sentencing State; (b) may not convert a sanction involving deprivation of liberty to a pecuniary sanction; (c) shall deduct the full period of deprivation of liberty served by the sentenced person; and (d) shall not aggravate the penal position of the sentenced person, and shall not be bound by any minimum which the law of the administering State may provide for the offence or offences committed. ${ }^{67}$

The Explanatory Report of the Convention on the Transfer of Sentenced Persons explains the difference between the two options in great detail. Because many pieces of prisoner transfer legislation have a provision that looks more or less like article 10 of the Convention on the Transfer of Sentenced Persons (1985) it is the

State for Justice [2009] EWHC 1483 (Admin) para 87. The United Kingdom also refused to consent to the offender's transfer to The Netherlands as his sentence could be converted by the Dutch courts. See The Queen on the Application of Henry Max Shaheen v The Secretary of State for Justice [2008] EWHC 1195 (Admin).

66 The state that administers or enforces the sentence that has been imposed (the receiving state) by the sentencing state or the transferring state (the sending state).

67 Articles 10 and 11 should be read in conjunction with a 9 of the Council of Europe's Convention on the Transfer of Sentenced Persons (1985). 
author's view that the relevant paragraphs of the Explanatory Report on article 10 are worth reproducing in detail:

49. Where the administering State opts for the "continued enforcement" procedure, it is bound by the legal nature as well as the duration of the sentence as determined by the sentencing State (paragraph 1): the first condition ("legal nature") refers to the kind of penalty imposed where the law of the sentencing State provides for a diversity of penalties involving deprivation of liberty, such as penal servitude, imprisonment or detention. The second condition ("duration") means that the sentence to be served in the administering State, subject to any later decision of that State on, for example, conditional release or remission, corresponds to the amount of the original sentence, taking into account the time served and any remission earned in the sentencing State up to the date of transfer.

50. If the two States concerned have different penal systems with regard to the division of penalties or the minimum and maximum lengths of sentence, it might be necessary for the administering State to adapt the sanction to the punishment or measure prescribed by its own law for a similar offence. Paragraph 2 allows that adaptation within certain limits: the adapted punishment or measure must, as far as possible, correspond with that imposed by the sentence to be enforced; it must not aggravate, by its nature or duration, the sanction imposed in the sentencing State; and it must not exceed the maximum prescribed by the law of the administering State. In other words: the administering State may adapt the sanction to the nearest equivalent available under its own law, provided that this does not result in more severe punishment or longer detention... [T] he procedure under Article 10.2 enables the administering State merely to adapt the sanction to an equivalent sanction prescribed by its own law in order to make the sentence enforceable. The administering State thus continues to enforce the sentence imposed in the sentencing State, but it does so in accordance with the requirements of its own penal system.

One needs to comment on how continued enforcement would work in South Africa. If a South African national is, for example, convicted of premeditated murder in Zimbabwe and the court finds that there are extenuating circumstances ${ }^{68}$ and he is sentenced to life imprisonment, his sentence in Zimbabwe would be governed by section 344A of the Criminal Procedure and Evidence Act which provides that:

[s]ubject to any other law, the effect of a sentence of imprisonment for life imposed on or after the date of commencement of the Criminal Procedure and Evidence Amendment Act, 1997, shall be that the person so sentenced shall remain imprisoned for the rest of his life. 
On the other hand, an offender convicted of premeditated murder in South Africa has to be sentenced to life imprisonment unless there are substantial and compelling circumstances to justify the imposition of a lesser sentence. ${ }^{69}$ In the Zimbabwean example, the nature of the sentence is compatible with South African law as South African law allows the imposition of the sentence of life imprisonment. However, the duration of the sentence is incompatible with South African law. Section 73(6)(b) of the South Africa's Correctional Services $A C{ }^{70}$ provides that "[a] person who has been sentenced to... (ii) life incarceration, may not be placed on day parole or parole until he or she has served at least 25 years of the sentence" and the same Act provides under section 73(6)(b)(vi) that a person sentenced to "any term of incarceration, excluding persons declared dangerous criminals ... may be placed on day parole or parole on reaching the age of 65 years provided that he or she has served at least 15 years of such sentence." The Supreme Court of Appeal has held that "it is the possibility of parole which saves a sentence of life imprisonment from being cruel, inhuman and degrading punishment."71

Indeed, courts, including the Constitutional Court, have ordered the Department of Correctional Services to consider the placement on parole of offenders sentenced to life imprisonment. ${ }^{72}$ What would happen in such a case is for the relevant prisoner transfer agreement or legislation in South Africa to provide for the adaptation of the sentence in question. There are different ways of doing this. In Mauritius it is the offender who must apply for such adaptation ${ }^{73}$ while in other countries such as Uganda $^{74}$ and Namibia ${ }^{75}$ it is done by the relevant government office. If a South African has been sentenced to life imprisonment in Malawi, for example, after the coming into force of the Malawian Prisons Bill ${ }^{6}$ in terms of which an offender sentenced to life imprisonment is supposed to be considered for parole after serving

\footnotetext{
Sections 51 and 53 of the Criminal Law Amendment Act 105 of 1997. Correctional Services Act 111 of 1998.

See S v Bull 2001 ZASCA 105 (26 September 2001) para 23.

See for example Van Vuren v Minister of Correctional Services 20121 SACR 103 (CC).

See s 6(3) of the Transfer of Prisoners Act 10 of 2001.

Section 15(2) of the Transfer of Convicted Offenders Act of 2012.

Section 13(2) of the Transfer of Convicted Offenders Act 9 of 2005.

See the Malawian Prisons Bill of 2003.
} 
12 years' imprisonment, ${ }^{77}$ the nature of the sentence would be compatible with South African law but its duration incompatible therewith. In this case, although such an offender's sentence could be adapted to one of life imprisonment in South Africa, he has to be considered for parole after serving 12 years. This is so because if his life sentence were to be governed by South African parole law, he would have to spend more time in prison than if he had served his sentence in Malawi, before being considered for parole.

However, there could be situations where South Africa could be allowed to convert the sentence in question. These are governed by article 11 of the Convention on the Transfer of Sentenced Persons (1985), referred to above. South Africa would first have to ratify that Convention. The Explanatory Report provides that:

51. Article 11 concerns the conversion of the sentence to be enforced, that is the
judicial or administrative procedure by which a sanction prescribed by the law of
the administering State is substituted for the sanction imposed in the sentencing
State, a procedure which is commonly called "exequatur". The provision should
be read in conjunction with Article 9.1 . $b$. It is essential for the smooth and
efficient functioning of the convention in cases where, with regard to the
classification of penalties or the length of the custodial sentence applicable for
similar offence, the penal system of the administering State differs from that of
the sentencing State.

52. The article does not regulate the procedure to be followed. According to paragraph 1 , the conversion of the sentence is governed by the law of the administering State.

The Explanatory Report ${ }^{78}$ adds that the reason why the administering state is bound by the facts and findings of the court in the sentencing state is that:

...the substitution by a sanction of a different nature or duration does not imply any modification of the judgment; it merely serves to obtain an enforceable sentence in the administering State.

The Convention "does not prevent conversion to a non-custodial sanction other than a pecuniary one. ${ }^{179}$ It is important to note that in the case of conversion, South

\footnotetext{
77 Clause 53(1)(b) of the Malawian Prisons Bill of 2003.

78 Council of Europe Date Unknown http://bit.ly/132UJpp paras 11 and 54.

79 Council of Europe Date Unknown http://bit.ly/132UJpp paras 11 and 55.
} 
African courts would have almost complete freedom to impose the sentence they deem fit. This means that if an offender has been sentenced to life imprisonment, for example, and transferred to South Africa, under article 11 South Africa would be at liberty to convert the sentence into one of imprisonment for a very short period of time. Because conversion would almost always benefit the offender, jurisprudence emanating from the European Court of Human Rights shows that some offenders would plead guilty or confess to the commission of offences on condition that their sentences would be transferred to their countries of nationality and that those countries would be allowed to convert the sentence. ${ }^{80}$

It is recommended that in framing a prisoner transfer agreement or arrangement, South Africa should provide for both options - continued enforcement and conversion. It is not clear why legislation on the transfer of offenders in Africa does not provide for the conversion of sentences. This could be attributed to the fact that most if not all of these pieces of legislation are modelled on the Scheme for the Transfer of Offenders in the Commonwealth (1990), which does not provide for the conversion of sentences. ${ }^{81}$

As indicated earlier, one of the options available to South Africa is to ratify the Convention on the Transfer of Sentenced Persons (1985). It is critical to look at the approaches that different countries have taken in relation to the issue of continued enforcement versus conversion. Some countries such as the United Kingdom, Andorra, Bahamas, Belgium, Ireland, Japan, Korea, Luxemburg, Spain, and Switzerland have made it very clear that they would exclude the conversion procedure "in cases when the [the country in question] is the administering State." ${ }^{12}$ This means that offenders transferred to these countries cannot have their

\footnotetext{
80 See Smith $v$ Germany Application No 27801/05 (1 April 2010) paras 40-41. See also Buijen $v$ Germany Application No 27804/05 (1 April 2010) paras 41-42.

81 See a 12 of the Scheme on the Transfer of Sentenced Persons within the Commonwealth (1990), which provides for continued enforcement.

82 See the list of declarations made with respect to Treaty No 112 at Council of Europe 2013 http://www.bit.ly/18vzUZd.

82 Council of Europe $2013 \mathrm{http}: / / w w w . b i t . l y / 18 \mathrm{vzUZd}$.
} 
sentences converted. ${ }^{83}$ Mexico made a declaration that the conversion procedure "will not apply if the Mexican Government is the State answering favourably to a request." ${ }^{184}$ France made a declaration that it "intends to exclude the application of the [conversion] procedure...in its relations with the other Parties. ${ }^{185}$ Italy, Malta, and Liechtenstein exclude the application of the conversion procedure whether they are the sentencing or administering states. ${ }^{86}$ Some countries such as Georgia and Russia made reservations on ratifying the Convention that they will not accept the continued enforcement of sentences. ${ }^{87}$ Any country transferring offenders to Georgia or Russia has to accept that these countries will convert the sentence in question. The Republic of San Marino will allow continued enforcement only in "special cases" and if it is the administering state, but as a general rule it will convert the sentences imposed on the transferred offenders. Greece makes it very clear that it "excludes the application of the [conversion] procedure ... By way of exception, if a sentenced person cannot be transferred to Greece" under the continued enforcement procedure, "the Greek Ministry of Justice is competent to decide whether the [conversion] procedure....will be followed." ${ }^{188}$ What emerges from the above is that different countries have adopted different approaches on the issue of conversion versus continued enforcement. Most of the countries have not made reservations or declarative interpretations on these issues. This means that these countries are open to continue the enforcement of a sentence or to convert a sentence. It is recommended that such an approach is the best to follow as it gives a statewide discretion to determine the manner in which to deal with the sentence of the sentenced offender.

83 For a discussion of the practice in the United Kingdom see Van Zyl Smit and Spencer "European Dimension to the Release of Sentenced Prisoners" 25-26.

84 Council of Europe $2013 \mathrm{http}: / / \mathrm{www} \cdot$ bit.ly/18vzUZd.

85 Council of Europe $2013 \mathrm{http}: / /$ www.bit.ly/18vzUZd.

86 Council of Europe $2013 \mathrm{http}: / /$ www.bit.ly/18vzUZd.

87 Council of Europe $2013 \mathrm{http}: / /$ www.bit.ly/18vzUZd.

88 Council of Europe $2013 \mathrm{http}: / /$ www.bit.ly/18vzUZd. 


\section{$5 \quad$ Prison conditions}

One issue that the South African government has to consider seriously is that of the conditions of the prisons in the country and how that could affect the transfer of offenders to South Africa. The fact that prisons are overcrowded has been repeatedly emphasised by the Judicial Inspectorate of Correctional Centres and overcrowding has reached such a level that South African courts have taken judicial notice thereof. ${ }^{89}$ The South African Constitutional Court recently held that the poor conditions in one of the prisons in South Africa led to one prisoner being infected with tuberculosis. ${ }^{90}$ The poor prison conditions in South African have also been a concern for international and regional human rights bodies such as the Committee against Torture, ${ }^{91}$ the Human Rights Committee ${ }^{92}$ and the African Commission on Human and Peoples' Rights. ${ }^{93}$ Warders are reputed to be assaulting inmates and the number of unnatural deaths remains high. ${ }^{94}$ It is argued that some offenders could object to their transfer to serve their sentences in South Africa on the basis that they would be imprisoned in prison conditions that would violate their right not to be subjected to cruel, inhuman or degrading treatment or punishment, which is guaranteed in many constitutions of different countries in the world as well as in international human rights instruments such as the $\mathrm{ICCPR}^{95}$ and the African Charter. ${ }^{96}$ In the light of the fact that torture is alleged to be committed in some

89 In $S v$ Brophy 20072 SACR 56 (W) para 18, it was held that: "Judicial cognisance can also be taken of the gross overcrowding in prisons housing awaiting-trial prisoners. On a prison visit I have seen such conditions. As appears from the annual reports of...the Inspecting Judge of Prisons, these harsh conditions have not been ameliorated." In $S v$ Jacobs 20111 SACR 490 (ECP) par 12: "[c]ourts can now in any event take judicial notice of the fact that the country's prisons are grossly overcrowded, particularly the awaiting-trial sections, and that a large number of the awaiting-trial prisoners have been granted bail and cannot afford to pay the bail, which is sometimes a small amount."

$90 \quad$ Lee $v$ Minister of Correctional Services 20132 SA 144 (CC).

91 Committee against Torture $2006 \mathrm{http}: / /$ bit.ly/1aoRW2P para 22.

92 Bradley McCallum $v$ South Africa Communication No 1818/2008 UN Doc CCPR/C/100/D/1818/2008 (2010).

93 See generally African Commission on Human and Peoples' Rights $2005 \mathrm{http}: / / \mathrm{bit} . l y / 14 \mathrm{gRJep}$.

94 See Department of Correctional Services Annual Report of the Judicial Inspectorate 2011/2012 37, 51-52.

95 Article 7 of the ICCPR.

96 Article 5 of the African Charter provides that: "[e]very individual shall have the right to the respect of the dignity inherent in a human being and to the recognition of his legal status. All forms of exploitation and degradation of man particularly slavery, slave trade, torture, cruel, inhuman and degrading punishment and treatment shall be prohibited." For a detailed discussion 
South African prisons, some states may invoke article 3 of the Convention Against Torture and Other Cruel, Inhuman or Degrading Treatment or Punishment (1985) (hereafter the Convention Against Torture) which provides that "[n]o State Party shall expel, return ('refouler') or extradite a person to another State where there are substantial grounds for believing that he would be in danger of being subjected to torture" in order to refuse to transfer South Africans to South Africa to serve their sentences. It should also be recalled that although the Convention Against Torture does not bar states parties from transferring persons to countries where they could be subjected to cruel, inhuman or degrading treatment, states parties have an obligation under article 16 to ensure that a person in their territory is not sent to a country where his or her right to freedom from cruel, inhuman or degrading treatment or punishment would be violated. In fact, poor prison conditions in some countries, such as, Jamaica, Uganda and Nigeria have been seen as likely to make it difficult for the United Kingdom to transfer offenders to those countries, with the result that the United Kingdom government has reportedly offered to renovate prisons in those countries so that it can transfer offenders. ${ }^{97}$ Poor prison conditions featured prominently in a case in which the South African government sought to extradite an offender from the United Kingdom to South Africa to stand trial for allegedly contracting people to murder his wife. ${ }^{98}$

Related to the above is the fact that the main reason for prisoner transfer, at least in theory, is that offenders would be better rehabilitated if they served their sentences in their home countries to which they, or most of them, would return, after the completion of their sentences. ${ }^{99}$ The rehabilitation of offenders as the reason for transfers is, however, absent from the legislation on prisoner transfer in African countries. It is not far-fetched to argue that prisoner transfers are increasingly being influenced not by social rehabilitation but rather by the desire of the sending country, especially the rich countries, to get rid of foreign offenders who have

of the measures taken by the African Commission to promote and protected the right to freedom from torture in Africa, see Mujuzi 2006 AHRL 423-441; Long and Murray 2012 AHRLJ311-347. See Baguma 2009 http://www.bit.ly/1bGpVEi; and Slack 2009 http://www.dailym.ai/u0QoT. See Morris $2011 \mathrm{http}: / /$ www.bit.ly/vkXXZm.

See Van Zyl Smit and Spencer "European Dimension to the Release of Sentenced Prisoners" 43. 
broken their laws. ${ }^{100}$ This could explain why some countries are resorting to compulsory transfers - that is, removing the requirement of the offender's consent to a transfer. ${ }^{101}$ Assuming that some countries would transfer offenders to South Africa only on condition that they would be rehabilitated, the present situation in most South African prisons with regard to rehabilitation would be a stumbling block. Many prisoners have no access to rehabilitation programmes ${ }^{102}$ as the Department of Correctional Services spends very little on rehabilitation and the prisons are overcrowded. The need to improve prison conditions cannot be over-emphasised.

\section{Conclusion}

Although for many years South Africa has been reluctant to enter into prisoner transfer agreements or arrangements, there is evidence that this position is likely to change. This article has highlighted some of the issues that the South African authorities would have to grapple with in implementing prisoner transfer agreements, in particular when they involve transferring offenders to South Africa. It is evident that the issue of human rights is critical in prisoner transfer arrangements and it is most likely to be one of the critical issues in determining either whether an offender will be transferred to South Africa or will continue to serve his sentence in

100 It has been argued by Van Zyl Smit and Spencer "European Dimension to the Release of Sentenced Prisoners" 43 that: "[w]hile the early Council of Europe instruments in particular were designed to meet humanitarian concerns for offenders who were held in countries other than their own and were thus less likely to be 'socially rehabilitated', the focus has increasingly shifted to the interests of the sentencing states. These states often want troublesome foreign offenders to be returned to their home countries, not because the offenders' interests would be better served by being returned, but because the sentencing states want to be rid of them to reduce the burden they place on overstretched resources for the implementation of sentences." It has been argued by Bassiouni "United States Policies and Practices" 588 that: "[t]he main problems facing a foreign prisoner are the cultural and language barrier, the lack of rehabilitation programmes and refusal of conditional release programmes (due to the perceived flight risk), and the general prejudice faced by the foreign prisoner, other prisoners, and prison staff. Prisoner transfer agreements were seen as a way to alleviate these additional burdens on the foreign prisoner. However, it would appear that these treaties are now also seen as a method by which the sentencing country can expel foreign prisoners and relieve itself of a considerable financial strain, which is a motive which runs contrary to the humanitarian goals of these treaties."

101 For example, the agreements between the United Kingdom and Libya and Rwanda do not require the offender's consent before the transfer. See a 4(3) (Libya); a 2(3) (Rwanda). The treaty with Rwanda expressly mentions that the offender's consent will not be required for the transfer to take place. 
South Africa. In the light of the fact that South Africa has a Constitution which includes a Bill of Rights and is also a party to international and regional human rights instruments, it is recommended that in any prisoner transfer agreement or arrangement the rights of offenders to be transferred to South Africa should take centre stage. For example, these treaties should provide for the rights to freedom from torture or cruel, inhuman or degrading treatment or punishment, and an offender's right to challenge the transfer decision before a court of law if needs be. It is also recommended that South Africa could adopt different approaches to regulate the transfer of offenders, which means that all of the approaches discussed above should be considered. South Africa should enact prisoner transfer legislation to enable it to transfer offenders with countries with which it does not have a prisoner transfer bilateral treaty or which are not parties to a multilateral treaty to which South Africa is party, should enter into bilateral prisoner transfer agreements or arrangements, and should also ratify or accede to multilateral prisoner transfer treaties. This would give as many South Africans as possible an opportunity to be transferred to South Africa to serve the remainder of their sentences. As regards the enforcement of sentences, it is recommended that South Africa retains the options of continued enforcement and conversion of the transferred sentence. This would ensure that transfers take place between countries that allow conversion of sentences into South African sentences, as well as those that allow transfers only in cases where South Africa will continue with the enforcement of the transferred sentences. 


\section{Bibliography}

Abbell International Prisoner Transfer

Abbell M International Prisoner Transfer (Martinus Nijhoff The Hague 2010)

Bassiouni "United States Policies and Practices"

Bassiouni MC "United States Policies and Practices on Execution of Foreign Sentences" in Bassiouni MC (ed) International Criminal Law: Multilateral and Bilateral Enforcement Mechanisms Volume II $3^{\text {rd }}$ ed (Martinus Nijhoff The Hague 2008) 551-590

Currie and De Waal Bill of Rights Handbook

Currie I and De Waal J The Bill of Rights Handbook $5^{\text {th }}$ ed (Juta Cape Town 2005)

Department of Correctional Services Annual Report 2011/2012

Department of Correctional Services Annual Report 2011/2012 (The Department Pretoria 2012)

Department of Correctional Services Annual Report of the Judicial Inspectorate $2011 / 2012$

Department of Correctional Services Annual Report of the Judicial Inspectorate for Correctional Services 2011/2012 (The Department Pretoria 2012)

Dugard International Law

Dugard J International Law: A South African Perspective 3rd ed (Juta Cape Town 2005)

Long and Murray 2012 AHRL

Long $\mathrm{D}$ and Murray $\mathrm{R}$ "Ten Years of the Robben Island Guidelines and Prevention of Torture in Africa: For What Purpose?" 2012 AHRL 311-347 
Mujuzi 2006 AHRLJ

Mujuzi JD "An Analysis of the Approach to the Right to Freedom from Torture adopted by the African Commission on Human and Peoples' Rights" 2006 AHRL 423-441

Schwikkard "Arrested, Detained and Accused Persons"

Schwikkard PJ "Arrested, Detained and Accused Persons" in Currie I and De Waal J (ed) The Bill of Rights Handbook $5^{\text {th }}$ ed (Juta Cape Town 2005) 737797

Van Zyl Smit and Spencer "European Dimension to the Release of Sentenced Prisoners"

Van Zyl Smit D and Spencer JR "The European Dimension to the Release of Sentenced Prisoners" in Padfield N et al (eds) Release from Prison: European Policy and Practice (Willan Publishing Devon 2010) 9-46

Wan 2008 Brook J Int'/ L

Wan CD "Prisoner Transfer between Hong Kong and Mainland China: A Preliminary Assessment" 2008 Brook J Int'l L 463-501

\section{Register of cases}

Bogaards v S2013 1 SACR 1 (CC)

Bradley McCallum $v$ South Africa Communication No 1818/2008 UN Doc CCPR/C/100/D/1818/2008 (2010)

Buijen v Germany Application No 27804/05 (1 April 2010)

Drozd and Janousek v France and Spain Application No 12747/87 (26 June 1992)

Egyptian Initiative for Personal Rights and Interights $v$ Arab Republic of Egypt Communication No $334 / 06$ (decided at the $9^{\text {th }}$ extra-ordinary session held from 23 February to 3 March 2011)

Ferreira v Levin; Vryenhoek v Powell 19961 SA 984 (CC)

Gareth Anver Prince v South Africa 1474/2006 (Human Rights Committee) 
Garreth Anver Prince v South Africa Communication No 255/02 (African Commission on Human and Peoples' Rights)

Glenister v President of the Republic of South Africa 20113 SA 347 (CC)

Kaunda v President of the Republic of South Africa 20054 SA 235 (CC)

Lee v Minister of Correctional Services 20132 SA 144 (CC)

Mapule v S 2012 ZASCA 80 (30 May 2012)

Mthembi-Mahanyele v Mail \& Guardian Ltd 20043 All SA 511 (SCA)

Oldwage $v$ Louwrens 20041 All SA 532 (C)

Omar Othman Aka Abu Qatada v Secretary of State for the Home Department [2013] EWCA Civ 277

Patricia Gerber v Government of the Republic of South Africa 2010 ZAGPPHC 240 (9

December 2010)

Pharmaceutical Manufacturers Association of South Africa: In re Ex Parte President of the Republic of South Africa 20002 SA 674 (CC)

$S$ v Brophy 20072 SACR 56 (W)

$S$ v Bull 2001 ZASCA 105 (26 September 2001)

S v Dzukuda; S v Tshilo 20002 SACR 443 (CC)

$S v$ Jacobs 20111 SACR 490 (ECP)

$S$ v Mofokeng 20131 SACR 143 (FB)

$S$ v Mthembu 20082 SACR 407 (SCA)

Samantha Orobator $v$ Governor of HMP Holloway and Secretary of State for Justice [2010] EWHC 58 (Admin)

Smith v Germany Application No 27801/05 (1 April 2010)

South African Broadcasting Corporation Limited v Thatcher 20054 All SA 353 (C)

Stoichkov v Bulgaria Application No 9808/02 (24 March 2005)

The Queen on the Application of Henry Max Shaheen $v$ The Secretary of State for Justice [2008] EWHC 1195 (Admin)

The Queen on the Application of: Steven Willcox $v$ Secretary of State for Justice [2009] EWHC 1483 (Admin)

Van Vuren v Minister of Correctional Services 20121 SACR 103 (CC) 


\section{Register of legislation}

Canadian International Transfer of Offenders Act of 2004

Constitution of the Republic of South Africa, 1996

Correctional Services Act 111 of 1998

Criminal Law Amendment Act 105 of 1997

Criminal Procedure Act 51 of 1977

Criminal Procedure and Evidence Act [Chapter 9:07] (Zimbabwe)

Malawian Prisons Bill of 2003

Transfer of Convicted Offenders Act 9 of 2005 (Namibia)

Transfer of Convicted Offenders Act of 2012 (Uganda)

Transfer of Convicted Offenders Bill of 2000

Transfer of Prisoners Act 10 of 2001 (Mauritius)

\section{Register of international instruments}

African Charter on Human and Peoples' Rights (1981)

Convention against Torture and Other Cruel, Inhuman or Degrading Treatment or Punishment (1985)

Council of Europe's Convention on the Transfer of Sentenced Persons (1985)

Inter-American Convention on Serving Criminal Sentenced Abroad (1993)

International Covenant on Civil and Political Rights (1966)

Scheme on the Transfer of Sentenced Persons within the Commonwealth (1990)

United Nations Convention against Corruption (2003)

United Nations Convention against Transnational Organised Crime (2000)

United Nations Model Treaty on the Transfer of Convicted Persons (1985)

\section{Register of agreements and treaties}

Agreement between the Government of the United Kingdom of Great Britain and Northern Ireland and the Republic of Uganda on the Transfer of Convicted Persons (2 June 2009) 
Agreement between the Government of the United Kingdom of Great Britain and Northern Ireland and the Government of the Republic of Ghana concerning the Transfer of Prisoners (17 July 2008)

Agreement between the Government of the United Kingdom of Great Britain and Northern Ireland and the Government of the Republic of Rwanda on the Transfer of Sentenced Persons (11 February 2010)

Agreement between the Government of the United Kingdom of Great Britain and Northern Ireland and the Government of the Kingdom of Morocco on the Transfer of Convicted Offenders (21 February 2002)

Agreement between the Government of the United Kingdom of Great Britain and Northern Ireland and the Government of Antigua and Barbuda on the Transfer of Prisoners (23 June 2003)

Agreement between the Government of the United Kingdom of Great Britain and Northern Ireland and the Government of the Federative Republic of Brazil on the Transfer of Prisoners (20 August 1998)

Agreement between the Government of the United Kingdom of Great Britain and Northern Ireland and the Government of Barbados on the Transfer of Sentenced Persons (3 April 2002)

Agreement between the Government of the United Kingdom of Great Britain and Northern Ireland and the Government of the Government of the Republic of Cuba on the Transfer of Prisoners (13 June 2002)

Agreement between the Government of the United Kingdom of Great Britain and Northern Ireland and the Republic of Nicaragua on the Transfer of Prisoners (6 September 2005) 
Agreement between the Government of the United Kingdom of Great Britain and Northern Ireland and the Government of the Government of the Dominican Republic on the Transfer of Prisoners (18 February 2003)

Agreement between the Government of the United Kingdom of Great Britain and Northern Ireland and the Government of the Bolivarian Republic of Venezuela on the Transfer of Sentenced Persons (12 June 2002)

Agreement between the Government of the United Kingdom of Great Britain and Northern Ireland and the Government of the Republic of India on the Transfer of Convicted Persons (18 February 2005)

Agreement between the Government of the United Kingdom of Great Britain and Northern Ireland and the Government of St Lucia on the Transfer of Prisoners (27 April 2006)

Agreement between the Government of the United Kingdom of Great Britain and Northern Ireland and the Government of the Cooperative Republic of Guyana on the Transfer of Prisoners (5 April 2002)

Agreement between the Government of the United Kingdom of Great Britain and Northern Ireland and the Government of the Islamic Republic of Pakistan on the Transfer of Prisoners (24 August 2007)

Agreement between the Government of the United Kingdom of Great Britain and Northern Ireland and the Government of the Republic of Peru on the Transfer of Sentenced Persons (7 March 2003)

Agreement between the Government of the United Kingdom of Great Britain and Northern Ireland and the Government of the Democratic Socialist Republic of Sri Lanka on the Transfer of Prisoners (6 February 2003) 
Agreement between the Government of the United Kingdom of Great Britain and Northern Ireland and the Kingdom of Saudi Arabia on the Transfer of Sentenced Persons (2 January 2012)

Agreement between the Government of the United Kingdom of Great Britain and Northern Ireland and the Government of the Republic of Suriname on the Transfer of Prisoners (29 June 2002)

Agreement between the Government of the United Republic of Tanzania and the Government of the Republic of Mauritius on the Transfer of Convicted Offenders (First Schedule to the Transfer of Prisoners (Republic of Tanzania)) (2008)

Treaty between the Government of the United Kingdom of Great Britain and Northern Ireland and the Great Socialist People's Libyan Arab Jamahiriya on the Transfer of Prisoners (17 November 2008)

Treaty between the Government of the United Kingdom of Great Britain and Northern Ireland and the Lao People's Democratic Republic on the Transfer of Sentenced Persons (7 May 2009)

Treaty between the Government of the United Kingdom of Great Britain and Northern Ireland and the Socialist Republic of Vietnam on the Transfer of Sentenced Persons (12 September 2008)

Agreement between the Government of the United Republic of Tanzania and the Government of the Republic of Mauritius on the Transfer of Convicted Offenders (2008)

\section{Register of internet sources}

African Commission on Human and Peoples' Rights 2005 http://bit.ly/14gRJep 
African Commission on Human and Peoples' Rights 2005 Report of the Special Rapporteur on Prisons and Conditions of Detention in Africa Mission to the Republic of South Africa 14-30 June 2004 http://bit.ly/14gRJep [date of use 27 April 2013]

allAfrica 2012 http://www.bit.ly/16d7zVL

allAfrica 2012 Mozambique: Prisoner Transfer Agreement with Malawi http://www.bit.ly/16d7zVL [date of use 27 April 2013]

allAfrica 2012 http://www.bit.ly/RBrlEU

allAfrica 2012 Zambia: Nation, Malawi Exchange Prison http://www.bit.ly/RBrlEU [date of use 24 July 2013]

Baguma 2009 http://www.bit.ly/1bGpVEi

Baguma R 2009 UK Funds Luzira Prison Rehabilitation http://www.bit.ly/1bGpVEi [date of use 27 April 2013]

Committee against Torture 2006 http://bit.ly/1aoRW2P

Committee against Torture 2006 Concluding Observations of the Committee against Torture on South Africa's Initial Report CAT/C/ZAF/CO/1 (7 December 2006) http://bit.ly/1aoRW2P [date of use 27 April 2013]

Correctional Services of Canada 2012 http://www.bit.ly/11kVSMX Correctional Services of Canada 2012 International Transfer of Offenders http://www.bit.ly/11kVSMX [date of use 27 April 2013]

Council of Europe 2013 http://www.bit.ly/15CifwK

Council of Europe 2013 Convention on the Transfer of Sentenced Persons http://www.bit.ly/15CifwK [date of use 27 April 2013] 
Council of Europe 2013 http://www.bit.ly/18vzUZd

Council of Europe 2013 List of Declarations Made with Respect to Treaty No 112 http://www.bit.ly/18vzUZd [date of use 27 April 2013]

Council of Europe Date Unknown http://www.bit.ly/132UJpp

Council of Europe Date Unknown Explanatory Note http://www.bit.ly/132UJpp [date on use 18 Jan 2013]

Department of Correctional Services 2010 http://www.bit.ly/KVL7tz

Department of Correctional Services 2010 Foreign Incarceration Levels http://www.bit.ly/KVL7tz [date of use 12 Dec 2012]

Jones 2009 http://www.bit.ly/11kVgGY

Jones M 2009 SA Drug Mules Could Rot Behind Bars http://www.bit.ly/11kVgGY [date of use 27 April 2013]

Lusaka Times 2011 http://www.bit.ly/1aEjCy4

Lusaka Times 2011 Zambia and Mozambique Sign MoU on the Transfer of Convicted Persons http://www.bit.ly/1aEjCy4 [date of use 27 April 2013]

Mhlana 2012 http://www.bit.ly/128pSHi

Mhlana Z 2012 Prison Deal Might Help Locals in Foreign Jails http://www.bit.ly/128pSHi [date of use 12 Dec 2012]

Modern Ghana News 2010 http://www.bit.ly/17UXP6P

Modern Ghana News 2010 Ghana, Nigeria to Exchange Prisoners http://www.bit.ly/17UXP6P [date of use 27 April 2013]

Morris 2011 http://www.bit.ly/vkXxZm

Morris S 2011 Shrien Dewani Would be Properly Cared for in South Africa, Court Hears http://www.bit.ly/vkXxZm [date of use 27 April 2013] 
OAS Date Unknown http://www.bit.ly/119Xt7T

OAS Date Unknown Signatories and Ratifications http://www.bit.ly/119Xt7T [date of use 27 April 2013]

Parliament UK 2012 http:www.//bit.ly/140XBSY

Parliament UK 2012 Prisoners: Repatriation http:www.//bit.ly/140XBSY [date of use 12 June 2013]

Pillay 2012 http://www.bit.ly/13PDc7N

Pillay G 2012 SA's Prisoner Transfer Agreement at Advanced State http://www.bit.ly/13PDc7N [date of use 14 Dec 2012]

PMG 2000 http://www.bit.ly/11kUVEf

PMG 2000 Transfer of Convicted Prisoners Draft Bill; Special Petitions:

Discussion http://www.bit.ly/11kUVEf [date of use 12 June 2013]

PMG 2001 http://www.bit.ly/13X2e3f

PMG 2001 Transfer of Convicted Prisoners Bill, Corruption Amd Bill, Fund for Victims of Crime Bill: Depts' Response http://www.bit.ly/13X2e3f [date of use 12 June 2013]

PMG 2012 http://www.bit.ly/12G8fF3

PMG 2012 Department of Correctional Services 2012 Strategic Plan: Input by Parliamentary Research Unit \& Stakeholders http://www.bit.ly/12G8fF3 [date of use 12 Dec 2012]

SAPA 2011 http://www.bit.ly/mHpaci

SAPA 2011 Most Foreign Prisoners from Zim, Moz http://www.bit.ly/mHpaci [date of use 27 April 2013] 
Slack 2009 http://www.dailym.ai/u0QoT

Slack J 2009 Britain 'to Build £1m Jail in Nigeria' for 400 Prisoners Serving Sentences Here http://www.dailym.ai/u0QoT [date of use 27 April 2013]

The Commonwealth Date Unknown http://www.bit.ly/YsnMVT

The Commonwealth Date Unknown South Africa http://www.bit.ly/YsnMVT [date of use 27 April 2013]

\section{List of abbreviations}

$\begin{array}{ll}\text { AHRL J } & \text { African Human Rights Law Journal } \\ \text { Brook J Int'I L } & \text { Brooklyn Journal of International Law } \\ \text { DCS } & \text { Department of Correctional Service } \\ \text { ICCPR } & \text { International Covenant on Civil and Political Rights } \\ \text { OAS } & \text { Organisation of American States } \\ \text { PMG } & \text { Parliamentary Monitoring Group } \\ \text { PTA } & \text { Prisoner Transfer Agreement } \\ \text { SAPA } & \text { South African Press Association } \\ \text { UK } & \text { United Kingdom }\end{array}$

